\title{
Social Media for Digital and Social Inclusion: Challenges for Information Society 2.0 Research \& Policies
}

\author{
Pieter Verdegem
}

Department of Informatics and Media, Uppsala University (Pieter.Verdegem@im.uu.se) Research Group for Media \& ICT, Ghent University and Interdisciplinary Institute for Broadband Technology (Pieter.Verdegem@UGent.be)

\begin{abstract}
In this paper we reflect on how research and policies can and/or should help in the development of a sustainable participatory information society for all. More specifically, we aim to investigate critically how social media can entail both potential and pitfalls, especially with regard to the difficult relationship between digital and social inclusion. First of all, traditional information society policies are scrutinized. Furthermore, we point at the existence of digital inequalities and we reflect briefly on policy intervention on e-inclusion. In addition, we also evaluate the raise of social media. Finally, attention is given to the challenge of how research can contribute to the participation of all in the information society.
\end{abstract}

Keywords: Information society policies, digital inequalities, social media and Web 2.0, digital and social inclusion.

Acknowledgement: This manuscript is an extended version of a paper that has been presented at the $3^{\text {rd }}$ ICTs and Society Meeting (June 29 - July 2, 2010; Internet Interdisciplinary Institute - IN3; Castelldefels - Barcelona, Spain), Paper session Inequalities: social, economic, political. The author would like to thank the valuable comments of the two reviewers: Christian Fuchs and an anonymous reviewer.

\section{Introduction}

The increasing dependence on information and communication technologies (ICT) in everyday life, both in our professional and private lives, forces us to reflect on how we can manage the digital era. For this reason, policymakers are actively involved in exploring conditions on how to take optimal benefit of the new opportunities that are being offered by ICT. After the rapid growth of the World Wide Web, starting from the mid-90s, the transformation towards an information society and knowledge economy became a hot topic on the policy agenda.

In Europe, the emergence of new technologies is perceived as one of most important driving forces to simultaneously make up arrears with the dominance of the United States and to uphold against new economic superpowers such as China, India or Brazil. In the light of this, ambitious dreams are formulated such as the so-called Lisbon Agenda. It is stated that this plan should enable:

To become the most competitive and dynamic knowledge-based economy in the world, capable of sustainable growth with more and better jobs and greater cohesion. (European Commission, 2000a).

Such claims clearly reflect a techno-enthusiastic vision on the information society and the knowledge economy. However, the existence of digital inequalities - more well-known as 'the digital divide' - is according to several (mainly scholarly) observers also a clear illustration that information society policies suffer from a technological deterministic spirit (Garnham, 2000; Golding, 2000; Goodwin \& Spittle, 2002; May, 2002). The latter refers to visions that consider ICT as the most important driver of the increase in societal prosperity, enabling the global use of new communication technologies that will eventually (and automatically) lead to a massive social and economical transformation. 
Despite the claims of technological determinism in the information society debate, a number of developments in recent years seem to have created the possibility to reserve a more central place of the user - as citizen and/or as consumer - within the digital era. We refer to emerging technologies and applications commonly named as 'social media' or 'Web 2.0'. Both in literature and in practice little consensus exists about an accurate definition of these new developments. However, a common characteristic seems to be that the user is given a more active role in comparison with 'traditional' ICT technologies. Therefore, the impact of social media may be understood as a first sign of re-engineering by society, as it marks a fundamental shift from technology driven innovation towards user and society driven innovation.

In this paper we reflect on how policies can and/or should help in the development of a sustainable participatory information society for all. By doing this, we aim to investigate critically how social media can entail both potential and pitfalls, especially with regard to the difficult relationship between digital and social inclusion. First of all, traditional information society policies are scrutinized. Furthermore, we point at the existence of digital inequalities and we reflect briefly on policy intervention in e-inclusion. In addition, we also evaluate the raise of social media (including Web 2.0). Finally, attention is given to the challenges of how research can contribute to the participation of all in a sustainable information society.

\section{Information Society Policies $\mathbf{1 . 0}$}

Although we cannot deny (the impact of) the increasing omnipresence of new media and ICT in everyday life, it seems to be difficult to accurately define what has to be understood under the concept of 'information society' (Alvarez \& Kilbourn, 2000; Garnham, 2000; Servaes \& Carpentier, 2006). It is the (multidisciplinary) subject of domains such as sociology, philosophy, economy, geography, information science. In order to overcome this conceptual vagueness, Frank Webster (2006) distinguishes five perspectives to study the information society: a technological, economical, sociological, geographical and cultural perspective. This pragmatic distinction may help in structuring the domain, however, it can also be criticized because causes and consequences are jumbled this way.

For this reason, we prefer to distinguish between the concept of 'knowledge economy' on the one hand and the concept of 'information society' on the other hand. The first concept refers to a techno-economic approach (Jessop, 2005) while the latter mainly deals with socio-cultural impacts (Martin, 2005). Although such a division may seem artificial as well, a number of authors defend this by arguing that revolutions in the economy and industry have particularly lead to the coming of an information society (Freeman \& Soete, 1994; Mansell \& Silverstone, 1996; Mansell \& Steinmueller, 2000).

The techno-economic focus has clearly dominated the first generation of information society policies. Following the techno-economic paradigm (Freeman \& Perez, 1998), the establishment of an information society became the goal in itself. Research \& Development (R\&D) is a key term in such conceptions and the dominant credo is that this would lead to technological progress and economic growth. Nonetheless, there are also (more) critical voices. Authors such as e.g. Manuel Castells ${ }^{1}$ refer to the concept of informationalism and state that the evolution towards an information society is a continuation or even a reinforcement of the capitalist logic of the system (Castells, 1996; Fuchs, 2008).

Therefore, in academia a strong plea is made for more thoughtful approaches of ICT in policy discussions (Mansell, 2008). More specifically, techno-optimistic visions have been criticized for mainly three reasons: (1) the weak empirical foundation that describes the increasing importance of information in society only in quantitative terms (Menou \& Taylor, 2006); (2) a technological determinism spirit that clearly dominates policies and that portrays citizenship dominantly in terms of consumerism (Servaes \& Heinderyckx, 2002) and (3) the widespread assumption that the

\footnotetext{
${ }^{1}$ Castells (1996) prefers the term 'network society' instead of 'information society' because every human society has always been characterized by information in his opinion.
} 
evolution towards an information society would evidently lead to (economical and societal) progress and to an increase of the quality of life ${ }^{2}$ (Hamelink, 2006).

Based on these critical notes, we can conclude that information society policies have been clearly dominated by techno-economic perspectives (Martin, 2005). In addition, Goodwin \& Spittle summarize this as follows:

Despite the articulation of a broad set of policy goals, it is argued that these discourses act to structure the debate in such a way that its economic parameters become privileged, at the expense of social and cultural factors. (2002, p. 225)

In this perspective, Manuel Castells' vision on the network society is particularly important to mention. He points to the socio-cultural consequences of informational capitalism (Castells, 1996, Fuchs, 2008). Inclusion in the network is a necessary condition to be able to participate in our society. According to Castells, providing access to ICT must be seen as a right of citizenship in the information age. However, he cautions for the influence of informational capitalism. A crucial social cleavage concerns those pushed to the margins of informational capitalism: the unskilled and educationally ill-prepared (Webster, 2006). According to our opinion, government should take responsibility in this by paying attention to (the link between) digital and social inclusion in information society policies and attaching equal importance to this as the techno-economic goals. In addition, it is important to critically reflect on statements that are (easily) made within policy documents.

\section{E-inclusion}

Despite the dominance of 'hard' economic objectives in policy visions on the information society, an important role is also defined for processes that indirectly contribute to this. Therefore, even in the early (neoliberal) discourse of the European Commission the aim for a better performing knowledge economy is - at least at first sight - linked with the striving for more social cohesion (Servaes \& Burgelman, 2000). In the first eEurope Action Plan it was stated:

eEurope is intended to accelerate positive change in the Union. It aims at ensuring this change towards the Information Society is cohesive, not divisive. Integrating, not fragmenting, An opportunity, not a threat. In essence, eEurope aims at bringing the benefits of the Information Society to the reach of all citizens. (European Commission, 2000b, p. 2)

Since the implementation of the eEurope program, the baseline of the policy discourse is 'an information society for all'. The first eEurope 2002 Action Plan was built around three major pillars: (1) investments in cheaper, faster and safer Internet access; (2) investments in people and skills and (3) to stimulate Internet uptake and use. Afterwards, the eEurope 2005 Action Plan has paid relatively less attention to digital inclusion while primarily focusing on thematic domains (that are related with Lisbon-goals): (1) e-government; (2) e-learning; (3) e-health and (4) e-business and ecommerce. However, cheaper internet access, safer networks and digital skills remained important points of attention. In 2005, the European Commission launched its i2010 strategy. In this program policy objectives are developed around: (1) creating a single information space; (2) increasing EU investments in ICT research and (3) promoting an inclusive European information society. Recently, the European Commission launched a new Europe 2020 strategy with the baseline 'A strategy for smart, sustainable and inclusive growth' (European Commission, 2010). The smart growth refers to developing an economy based on knowledge and innovation, sustainable growth aims at promoting a more resource efficient, greener and more competitive while (last but not least) inclusive growth should foster a high-employment economy delivering social and territorial

\footnotetext{
${ }^{2}$ Regarding the relationship between the transition towards an information society and the improvement of quality of life, Hamelink states: "Apart from the fact that there is no convincing empirical evidence about such causal connections, one could equally well argue that technological development and economic growth destroy quality of life (2004, p. 287)." His statement thus argues for (more) critical reflections in this area.
} 
cohesion. Summarizing, at (least at) first sight e-inclusion (as part of a social policy) seems to be a central pillar of all recent (European) policy visions.

But what should be understood under e-inclusion? To a certain extent, e-inclusion can be seen as policy intervention in order to reduce digital inequalities and to foster participation of all citizens to the information society. The digital divide has been the subject of a number of scholarly studies (see e.g. Norris, 2001; van Dijk, 2005; Warschauer, 2003). The concept of the digital divide itself appeared to be successful in putting the issue on the agenda of political, social and scholarly discussion, however, it is a simplification of reality and thus risks to introduce several misunderstandings. Especially the dichotomous portrayal ('haves' versus 'have-nots', 'technologically rich' versus 'poor') is no longer tenable as these conceptualizations are too limited and rudimentary in analysis (Barzilai-Nahon, 2006; Selwyn, 2004; van Dijk, 2006). Recent research also indicated that new theoretical frames of mind are needed in order to overcome digital inequalities (Selwyn \& Facer, 2007). 'Traditional' digital divide parameters (socio-demographic variables) allow to support differences in ICT access and use with evidence, however, for setting up new policy measures these parameters seem to be no longer sufficient (Verdegem \& Verhoest, 2009).

How can we accurately define and evaluate e-inclusion policies? E-inclusion is part of broader policy measures that aim to include all citizens in society and to foster social cohesion (Cammaerts et al., 2003). According to the European Commission (2001), e-inclusion consists of two clear dimensions: firstly, it focuses on preventing digital exclusion. This means that policy measures should prevent that (socially) disadvantaged groups are left behind in the development of the information society. Secondly, e-inclusion is about exploiting new opportunities for a better inclusion of socially disadvantaged people or groups, or less-favored areas.

In (recent) policy discussions on e-inclusion a major point of attention is the active involvement in society. In addition, e-inclusion can to a certain extent be seen as social inclusion in the knowledge society. Therefore, beyond access to ICT tools and services, beyond even digital literacy, a definition of e-inclusion should focus on people's empowerment and participation in the knowledge society and economy. Therefore, skills and competences, awareness and willingness, social capital - and the means to grow it - should be key factors of e-inclusion (Kaplan, 2005).

Despite the attention to e-inclusion we need a critical review of the statements and goals that are being put forward within the EU policy documents. Therefore, we need to better understand the underlying discourses (especially on the political level) about which society is desirable. As this is also part of normative discussions, it is important to have a grounded theoretical background about information societies at our disposal. Fuchs (2010a) distinguishes between four types of approaches on the sustainable information society: (1) reductionism; (2) projectionism; (3) dualism and (4) a dialectic approach. According to Fuchs EU policy documents seem to fall under the category 'reductionism' or 'dualism'. The first refers to a vision that sees ecology, economy, or technology as the driving forces of a sustainable information society. In the latter category multiple dimensions and goals of a sustainable information society are identified, but not causally related to each other (Fuchs, 2010a).

We can state that the EU discourse on the information society has shifted towards a reductionistic approach: the neoliberal agenda dominantly focuses on mainly economic goals. This is illustrated by e.g. the i2010 action plan which aims for an 'information society for growth and employment' (Commission of the European Communities, 2005). In addition, the question arises to what extent the striving for a better performing (knowledge) economy can be linked to ambitious goals such as e-inclusion and e-participation. Although some policy documents have the ambition to contribute to this debate, e.g. a policy view on a Green Knowledge Society under the Swedish EU presidency (Forge, Blackman, Bohlin, \& Cave, 2009), we need to further investigate how the 'official' EU agenda, e.g. the recently launched 'Digital Agenda' (European Commission, 2010) will evolve on this matter.

Furthermore, is increasingly important to reflect on the how social media and Web 2.0 can contribute in this discussion (Fuchs, 2008; Hassan \& Thomas, 2006). It is often stated that these 
services and applications may function as a lever to better support the role of active involvement and user empowerment, especially because the user is given a more central role in comparison with 'traditional' ICT and media technologies. Therefore, we need to better understand the increasing success of social media.

\section{The Potential and Pitfalls of Social Media}

The World Wide Web rapidly grew since the end of the 90s. The liberalization of the telecom industry and the reduced prices of personal computers spread the Internet into the households. No longer than a couple of years later, however, new developments came to the surface. In a report titled 'The Participative Web and User-Created Content' the OECD (2007) describes the rise and growth of a new type of intelligent web services which have enabled users to share, adapt and create content. These 'new' services are commonly labeled as social media and Web 2.0 (boyd \& Ellison, 2008; Castells, 2007; O'Reilly, 2005; Pascu, Broster, Cachia et al., 2008).

Although there exists a long tradition of research that examines the social aspects of computerization - e.g. the study field called 'social informatics' (Kling, Rosenbaum, \& Sawyer, 2005; Kling, 2007) - social media are increasingly omnipresent in our contemporary society and by consequence they have become an important research topic.

According to the literature, social media are open, web-based and user-friendly applications that provide new possibilities when it comes to the co-creation of content (blogs, wiki, Flickr, Twitter), social networking (Facebook, Netlog), the sharing of taste and relevance (Amazon, del.icio.us, Google Pagerank), connectivity (wifi sharing, mesh networks) and collective intelligence (business Web 2.0). Several scholars point at the disruptive potential of social media and Web 2.0 (Ala-Mutka et al., 2009; Hassan \& Thomas, 2006).

This movement seems to entail an economic as well as a socio-cultural impact. The economic impact is illustrated by the increasing strong position of 'new' companies such as Google who have turned the (new) media and ICT market upside-down. New business models (e.g. 'The Long Tail') (Anderson, 2004) or modes of organization (e.g. 'Wisdom of the Crowds') (Surowiecki, 2004) came to the surface and need to be investigated critically. On the socio-cultural level, we notice that users are becoming much more deeply involved in the process of production and service innovation. The distinctive roles of producers and consumers are beginning to collapse. The idea of 'prosumership' is not new, as coined by Toffler (1980) in his book 'Third Wave', however, it finally may become reality due to the new and emerging developments (Bruns, 2008). Summarizing, the impact of social media may be understood as a first sign of re-engineering by society, as it seems to mark a fundamental shift from technology driven innovation towards user and society driven innovation. This way, the technological deterministic approach of the information society (also in policies) may be challenged.

The diffusion and usage of social media applications have been growing dramatically. Ala-Mutka et al. (2009) state that these applications and services have become mainstream. Their research has revealed that by the end of 2008 (Ala-Mutka et al., 2009):

- $41 \%$ of all EU Internet users, and $64 \%$ of these aged under 24 , were engaged in social computing \& informatics activities;

- $32 \%$ of the European internet users had created a profile on a social networking site;

- Social networking sites alone were attracting an average of 165 million unique visitors a month (June 2008);

- In several OECD countries, more time was being spent on social networking and personal blogs than on e-mail;

- The number of blogs doubled from 2007 to more than 100 million worldwide, and more than 100,000 blogs were being created daily;

- More than 1 million photos and 40 million user-created videos have been uploaded onto photo and video-sharing sites. 
Nevertheless we need to look beyond the figures and we need to be aware of (a) different degrees of user participation: there is a clear distinction between active users (contributors) versus passive users (the so-called 'lurkers') (Pascu et al., 2008); and (b) usage divides: young people were quicker to adopt social media. In addition, other socio-economic variables (education, social class) or geographic variables (North-South) may explain differences in adoption. Both aspects force us to critically reflect on the potential and pitfalls of social media.

In addition to the aspects mentioned above, we may not neglect other aspects of the 'dark side' of Web 2.0. More specifically, the active role of the user - as a contributor of so-called 'usergenerated content on platforms such as YouTube, MySpace and Facebook' - seems to lead to new forms of exploitation and reorganization of labor in informational capitalism (Fuchs, 2010b). Users are becoming produsers by actively contributing with content and interaction. Simultaneously, however, they constitute an audience commodity that is sold to advertisers. Other aspects that should be taken into account is the issue of privacy and surveillance (see e.g. Andrejevic, 2006; Lyon, 2002). This refers to the question to what extent users are self-reflexive about and sufficiently aware of changes in privacy and personal data, i.e. how their digital activities are monitored, processed, analyzed and commodified by third parties.

All these aspects (amongst other) need to be taken into account by policymaking in the digital era. In the next paragraphs we seek to understand how research can contribute in this. We also need to consider how these insights can advise and inspire policymakers in their policies that aim to contribute to a sustainable participatory information society for all.

\section{Challenges for Research and Policy}

\subsection{Digital Inclusion versus Social Inclusion}

Digital access and capabilities in dealing with ICT have been identified as relevant for personal fulfillment and development, active citizenship, social inclusion and employment (van Dijk, 2005; Warschauer, 2003). Besides avoiding the emergence of new inequalities, digital inclusion contributes to social inclusion to the extent that people at risk of exclusion can be empowered through ICT. Social media may support the enhancement of citizens' social capital as it enables interactions between offline and online sociability and the enrichment of social relations by creating and maintaining links through the use of social networks. In addition, social media can also contribute to the development of cultural capital of disadvantaged people as it broadens the access to digital content and other opportunities which facilitate (informal) learning processes (Ala-Mutka et al., 2009).

However, social media are currently presented with a double face: it can possibly create new digital divides widening the gap created by digital and social exclusion for already vulnerable groups and people. Simultaneously it can also be an enabler of self-organization (Fuchs, 2008) and self-help processes started by, or involving, socially-excluded people that transform weak ties created across the online and offline worlds into effective collective structures of engagement and participation. Summarizing, in our research activities we should strive to better understand how the potential of social media can support user participation and user empowerment without creating new inequalities, both on the digital and on the social level. Especially on the empirical level, we need appropriate research data in order to (be able to) reflect critically on the (techno-enthusiastic) promises that have been made.

\subsection{The Need of (New) Theoretical Frameworks}

Given new developments and emerging societal trends (e.g. the success of social media but also the rise of mobile applications, the overlap between public and private life), it is clear that we need new theoretical frameworks that can support our analysis. In view of this Manuel Castells (2009) has introduced in his 'Communication Power' (which can be seen as a successor of his major 
trilogy about the information age) a new concept that will shape the (trans)disciplinary discussions about power and communication in the coming years: 'mass self-communication'.

It is mass communication because it reaches a potentially global audience through peer-topeer networks and Internet connection. It is multimodal, as the digitization of content and advanced social software, often based on open source programs that can be downloaded for free, allows the reformatting of almost any content in almost any form, increasingly distributed via wireless networks. It is also self-generated in content, self-directed in emission, and selfselected in reception by many who communicate with many. (Castells, 2009, pp. 70-71)

In other words, this is a new communication realm, and ultimately a new paradigm, whose backbone is made of computer networks, whose language is digital, and whose senders are globally distributed and globally interactive.

The concept provides an interesting framework for studying new and emerging developments in our rapidly evolving digital landscape as well as for investigating how the disruptive potential of technology can be employed for better social inclusion. However, it is not free of criticism. According to Jan van Dijk (2010), Castells is ignoring the problem of the digital divide and the lack of digital skills among a part of the population of Internet users, even in high-access countries. The (possible) liberating potential of mass self-communication will therefore be seen in another light when Internet use in practice would lead to a reinforcement of the 'information elite' and big problems to catch up for large parts of the population.

In addition, the concept of mass self-communication needs to be more accurately described and defined. This is lacking in 'Communication Power' and Castells also employs a rather technocratic language in his book (Fuchs, 2009). Consequently, without further conceptual refinement this concept may contribute to the emergence of a new technological deterministic - instead of a userdriven - spirit around social media and Web 2.0. In addition, this may also lead to too easy assumptions about the relationship between social and digital inclusion. Summarizing, we need to critically assess the theoretical frameworks that can help us studying the field and the emerging developments.

\subsection{Challenges on the Empirical Level}

Another question deals with the empirical approaches of our research in this field. Given the double face of social media we could argue to specifically focus on disadvantaged groups. On the other hand, it remains unclear whether this label accurately fits with different categories of user participation and/or usage divides (Pascu et al., 2008).

Therefore, our methodological toolkit at hand should also be critically evaluated. When it comes to the measurement and monitoring of digital skills and/or social \& cultural capital, it is clear that a single-method approach may be not sufficient at all. Therefore, we should consider to implement and combine new and emerging methods such as ethnography, social network analysis and other (emerging) user-centric research techniques.

Last but not least, the methodologies that are employed in the research should have close links with well-considered conceptual frameworks. More specifically, we should invest in better defining and trashing out (vague) concepts such as social media, user participation and user empowerment.

\subsection{Towards Policy-Oriented Action Research?}

More in general, another central question deals with the role of researchers in the process of policymaking. What is, can and should be our contribution in this? Should we just be 'neutral' observers (with a main focus on describing and explaining the complex reality) or is it our duty to (try to) really hold policymakers responsible for establishing a sustainable society that enables and encourages real participation of all citizens?

The answer on this question relates to normative discussions about the development of a sustainable participatory information society for all. In addition, our viewpoints on this are also 
linked with the research domain in which we are operating. Nevertheless, it is clear that we need a critical spirit when investigating new developments in the digital era. According to the famous scholar Paul Lazarsfeld (1941) critical studies perceive our society as the context in which we act in the process of communication. In addition, Lazarsfeld also states that critical communication studies discuss the desirable and undesirable effects of communication in society. By doing this, it should be examined how the desirable effects can be strengthened (at the expense of less desirable effects).

Therefore we need to have strong theoretical foundations and reliable empirical methods at our disposal. Because any empirical research unavoidably proceeds from certain normative assumptions, critical theory has to guide empirical research. Social criticism in theory and research is not adverse to empirical research, including quantitative research methods. In this context, Jürgen Habermas (2006) has stated that normative theory can build a bridge to political reality and serve as a guide to empirical research projects.

\section{By Means of Conclusion}

In this article we reflect on how research and policies can and/or should help in the development of a sustainable participatory information society for all. Our main attention is on the (possible) disruptive potential of social media and how the rise of these new services poses new challenges with regard to digital and social inclusion.

First of all, we discussed information society policies 1.0. These policies are clearly dominated by techno-enthusiastic visions and importantly influenced by a technological deterministic spirit. Nowadays, we should critically reflect on whether recent policy visions also (exclusively) aim for a better performing knowledge economy. This dominance of (hard) economic goals seem to go at the expense of social and cultural aspects.

Social media may function as a lever to realize user and society driven innovation instead of technology driven innovation. However, despite the success of these (new) services, critical analysis is necessary in order to assess whether social media indeed have potential to bridge the gap between digital and social inclusion. On the other hand, (potential) negative aspects related to social media and Web 2.0 may not be neglected.

In this contribution we have highlighted crucial aspects of the most important challenges for information society research and policies. First of all, the relationship between digital and social inclusion needs to be thoroughly investigated. In this context, empirical data need to be assembled to critically reflecting on the promises of social media. Secondly, in the rapid evolving digital age our theoretical frameworks at hand should be critically investigated. The concept of mass selfcommunication provides an interesting framework for studying (new) power relations in our computer-mediated society, however, it is not free of criticism. Thirdly, also on the empirical level we are confronted with the need of new methodological frameworks. Traditional single-method approaches seem to be no longer sufficient so we need to explore how and which methods can support the analysis of social media and their potentials and/or pitfalls. Lastly, a general aspect is the role of researchers in the process of policymaking.

As researchers it is our duty to advise and to inspire policymakers with regard to the establishment of an information society that enables and encourages real participation of all citizens. Critical analysis in this is indispensable as we are also obliged to hold policymakers responsible for giving equal attention to social and cultural goals in comparison with economic goals in information society policies.

\section{References}

Ala-Mutka, K., Broster, D., Cachia, R., Centeno, C., Feijóo, Haché, A., Kluzer, S., Lindmark, S., Lusoli, W., Misuraca, G., Pascu, C., Punie, Y. \& Valverde, J.A. (2009). The Impact of Social Computing on the EU Information Society and Economy. Luxembourg: Office for Official Publication of the European Communities. 
Alvarez, I., \& Kilbourn, B. (2002). Mapping the Information Society: Topics, perspectives, and Root Metaphors. First Monday 7 (1). Retrieved June 10, 2010 from http://firstmonday.org/htbin/cgiwrap/bin/ojs/index.php/fm/article/view/922/844.

Anderson, C. (2004, October). The long tail. Wired Magazine.

Andrejevic, M. (2006). The Discipline of Watching: Detection, Risk and Lateral Surveillance. Critical Studies in Media Communication 23(5), 391-407.

Barzilai-Nahon, K. (2006). Gaps and Bits: Conceptualizing Measurements for Digital Divide/s. The Information Society: An International Journal 22(5), 267-278.

boyd, d.m. \& Ellison, N.B. (2008). Social Network Sites: Definition, History, and Scholarship. Journal of Computer-Mediated Communication 13(1), 210-230.

Bruns, A. (2008). Blogs, Wikipedia, Second Life and Beyond: From Production to Produsage. New York: Peter Lang.

Cammaerts, B., Van Audenhove, L., Nulens, G., \& Pauwels, C. (2003). Beyond the Digital Divide: Reducing Exclusion, Fostering Inclusion. Brussels: VUB University Press.

Castells, M. (1996). The Rise of the Network Society. Oxford: Blackwell.

Castells, M. (2007). Communication, Power and Counter-Power in the Network Society. International Journal of Communication 1(1), 238-266.

Castells, M. (2009). Communication Power. Oxford, New York: Oxford University Press.

Commission of the European Communities (2005). 12010: A European Information Society for Growth and Employment. Brussels: Commission of the European Communities.

European Commission (2000a). Lisbon European Council - Presidency Conclusions. Retrieved June 12, 2010 from http://consilium.europa.eu/ueDocs/cms_Data/docs/pressData/en/ec/00100-r1.en0.htm.

European Commission (2000b). eEurope: An Information Society for All. Communication on a Commission Initiative for the Special European Council of Lisbon, 23 and 24 March 2000. Retrieved June 12, 2010 from http://epractice.eu/files/media/media_417.pdf.

European Commission (2001a). E-inclusion: The Information Society's Potential for Social Inclusion in Europe. Retrieved June 12, 2010 from http://ec.europa.eu/employment_social/knowledge_society/docs/eincl_en.pdf.

European Commission (2010). Europe 2020: A Strategy for Smart, Sustainable and Inclusive Growth. Communication from the Commission. Retrieved July 21, 2010 from http://europa.eu/press_room/pdf/complet_en_barroso__007_-_europe_2020_-_en_version.pdf

Forge, S., Blackman, C., Bohlin, E. \& Cave, M. (2009). A Green Knowledge Society: An ICT Policy Agenda to 2015 for Europe's Future Knowledge Society: A Study for the Ministry of Enterprise, Energy and Communications, Government Offices of Sweden. Retrieved December 12, 2010 from http://ec.europa.eu/information_society/eeurope/i2010/docs/i2010_high_level_group/green_knowledge_society.pdf.

Freeman, C., \& Perez, C. (1988). Techno-Sconomic Paradigm. In G. Dosi (Ed.), Technical Change and Economic Theory. London: Pinter Publishers.

Freeman, C., \& Soete, L. (1994). Work for All or Mass Unemployment: Computerised Technical Change Into the 21st Century. London: Pinter Publishers.

Fuchs, C. (2008). Internet and Society. Social Theory in the Information Age. New York/London: Routledge.

Fuchs, C. (2009). Some Reflections on Manuel Castells' Book "Communication Power". tripleC (cognition, communication, co-operation) - Open Access Journal for a Global Sustainable Information Society 7(1), 94-108.

Fuchs, C. (2010a). Theoretical Foundations of Defining the Participatory, Co-Operative, Sustainable Information Society. Information, Communication \& Society 13(1), 23-47.

Fuchs, C. (2010b). Labor in Informational Capitalism and on the internet. The Information Society 26(3), 179-196.

Garnham, N. (2000). 'Information Society' as Theory or Ideology: A Critical Perspective in Technology, Education and Employment in the Information Age. Information, Communication \& Society 3(2), 139-152.

Golding, P. (2000). Forthcoming Features: Information and Communication Technologies and the Sociology of the Future. Sociology 34(1), 165-184.

Goodwin, I., \& Spittle, S. (2002). The European Union and the Information Society: Discourse, Power and Policy. New Media and Society 4(2), 225-249.

Habermas, J. (2006). Further Reflections on the Public Sphere. In C. Calhoun (Ed.) Habermas and the Public Sphere (pp. 421-461). Cambridge: MIT Press.

Hamelink, C. J. (2004). Did WIS achieve anything after all? Gazette: The International Journal for Communication Studies 66(3-4), 281-290.

Hamelink, C. J. (2006). Rethinking ICTs: ICTs on a Human Scale. European Journal of Communication 21(3), 389-396.

Hassan, R. \& Thomas, J. (2006). The New Media Reader: A Critical Introduction. London/New York: Routledge.

Jessop, B. (2005). Cultural Political Economy, the Knowledge-Based Economy, and the State. In D. Slater \& A. Barry (Eds.) The Technical Economy (pp. 144-166). London: Routledge. 
Kaplan, D. (2005). E-inclusion: New challenges and Policy Recommendations: eEurope Advisory Group - Working Group 2 - e-Inclusion: Final report. Retrieved June 16, 2010 from http://www.epractice.eu/files/media/media_764.pdf.

Kling, R., Rosenbaum, H. \& Sawyer, S. (2005). Understanding and Communicating Social Informatics. Medford: Information Today.

Kling, R. (2007). What is Social Informatics and Why does it Matter? The Information Society 23(4), 205-220.

Lazarsfeld, P.F. (1941). Remarks on Administrative and Critical Communication Research. Studies in Philosophy and Science, 9, 3-16.

Lyon, D. (2002). Everyday Surveillance: Personal Data and Social Classifications. Information, Communication \& Society $5(2), 242-257$.

Mansell, R. (2008). The Life and Times of the Information Society: A Critical Review. Paper presented at the Fifth Anniversary Conference of the Department of Media and Communication, 'Media, Communication \& Humanity', London School of Economics and Political Sciences.

Mansell, R., \& Silverstone, R. (1996). Communication by Design: The Politics of Information and Communication Technologies. Oxford: Oxford University Press.

Mansell, R., \& Steinmueller, W. E. (2000). Mobilizing the Information Society: Strategies for Growth and Opportunity. Oxford: Oxford University Press.

Martin, B. (2005). Information Society Revisited: From Vision to Reality. Journal of Information Science 31(1), 4-12.

May, C. (2002). The Information Society: A Sceptical View. Cambridge: Polity Press.

Menou, M. J., \& Taylor, R. D. (2006). A 'Grand Challenge': Measuring Information Societies. The Information Society: An International Journal 22(5), 261-267.

Norris, P. (2001). Digital divide, Civic Engagement, Information Poverty and the Internet Worldwide. Cambridge: Cambridge University Press.

OECD (2007). Participative Web and User-Created Content, Web2.0, Wikis and Social Networking. Paris: OECD Publishing.

O'Reilly, T. (2005). What is Web 2.0? Design Patterns and Business Models for the Next Generation of Software. Retrieved June 20, 2010 from http://oreillynet.com/1pt/a/6228.

Pascu, C., Osimo, D., Turlea, G., Ulbrich, M., Punie, Y., \& Burgelman, J. C. (2008). Social Computing: Implications for the EU Innovation Landscape. Foresight 10(1), 37-52.

Selwyn, N. (2004b). Reconsidering Political and Popular Understandings of the Digital Divide. New Media and Society 6(3), 341-362.

Selwyn, N. \& Facer, K. (2007). Beyond the Digital Divide: Rethinking Digital Inclusion for the $21^{\text {st }}$ Century. Open Education Serices. Retrieved June 20, 2010 from http://www.futurelab.org.uk/resources/documents/opening_education/Digital_Divide.pdf

Servaes, J., \& Burgelman, J. C. (2000). In Search of a European Model for the Information Society. Telematics and Informatics 17(1-2), 1-7.

Servaes, J., \& Heinderyckx, F. (2002). The 'New' ICTs Environment in Europe: Closing or Widening the Gaps. Telematics and Informatics, 19(2), 91-115.

Servaes, J., \& Carpentier, N. (2006). Introduction: Steps to Achieve a Sustainable Information Society. In J. Servaes \& N. Carpentier (Eds.), Towards a Sustainable Information Society. Deconstructing WSIS (pp. 5-15). Bristol: Intellect.

Surowiecki, J. (2004). The Wisdom of the Crowds: Why the Many are Smarter than the Few. London: Abacus.

Toffler, A. (1980). The Third Wave. New York: Bantam Books.

van Dijk, J. A. G. M. (2006). Digital Divide Research, Achievements and Shortcomings. Poetics 34(4-5), 221-235.

van Dijk, J. A. G. M. (2005). The Deepening Divide: Inequality in the Information Society. London: Sage.

van Dijk, J. A. G. M. (in press). Review of Manuel Castells (2009) Communication power. Communications, the European Journal of Communication.

Verdegem, P. \& Verhoest, P. (2009). Profiling the Non-User: Rethinking Policy Initiatives Stimulating ICT Acceptance. Telecommunications Policy 33(10-11), 642-652.

Warschauer, M. (2003). Technology and Social Inclusion: Rethinking the Digital Divide. Cambridge: MIT Press.

Webster, F. (2006). Theories of the Information Society. London/New York: Routledge.

\section{About the Author}

Pieter Verdegem

Pieter Verdegem is currently affiliated to the Department of Informatics and Media, Uppsala University (Sweden) as a postdoctoral research fellow. He is also a senior researcher at the Research Group for Media \& ICT (IBBT-MICT), Ghent University (UGent) and at the Interdisciplinary Institute for Broadband Technology (IBBT) (Belgium). Pieter holds a master's degree in Communication Sciences and E-communications Studies. In 2009, he obtained a Ph.D. on government strategies 
in the information society, particularly e-government and e-inclusion. His research focuses on information society studies, ICT acceptance, critical theory, new media \& ICT policy, e-government and e-inclusion. Pieter is (co-)author of numerous scholarly publications in these fields. 